\title{
Effective Use of Waste Plastic as Bitumen Strength Modifier
}

\author{
Syed Nasir*, Muhammad Ayoub, Syed Zafarullah, Ahmed Bilal, Badar Amjad. Ehsanullah Kakar
}

Department of Civil Engineering, BUITEMS, Quetta

Copyright $@ 2014$ Horizon Research Publishing All rights reserved.

\begin{abstract}
Type of shopping bag that are made from various kinds of plastic mainly from low \& high density Polypropylene are carrier bags, shopping bags or plastic grocery bags. These are often called single-use bags as these are used to carrying stuff from a store to a home. The uses of these bags are increasing day by day due to rapid increase in population and growth in urban area. Plastic bags not only clog drainage systems but also contribute to flooding. Infrastructure of trash collection is less developed in Pakistan which causes a serious problem of littering. Plastics are friendly to consumer but are not environmental friendly due to their biodegradability. General methods to disposed waste plastic are either by incineration of materials or by way of land filling which are hazardous for human health and environment. This paper covers a new method to utilize waste plastic bags in modification of bitumen not to just effectively utilize waste plastics but also to improve strength properties of bitumen concrete mix of flexible pavement.
\end{abstract}

Keywords Low density polyethylene begs (LDPE), Marshall Stability, Marshall Flow and Hot Asphalt Mix

\section{Introduction}

Plastic bags are friendly use for a common man due to their low cost and easy use but on other hand they are a great threat to environment due to their non-biodegradability. As these cannot be disposed scientifically thus it creates ground and water pollution. These plastic bags not only clog drainage systems but also give an unaesthetic view to surrounding. As the solid waste management is not good in Pakistan which make these plastic begs a serious issue which needs to be highlighted and an alternative method should be adopted to utilize this waste plastic begs without harming and damaging the environment by any way. Thus one of great solution for this is to mix it with a suitable percentage with asphalt in road mix which not only utilize waste plastic but also modify asphalt and work as a strength modifier for asphalt. By this methods waste plastic is brought in to work without harming environment and this method is not just ecofriendly but also economical because some amount of asphalt is replaced by waste plastic which reduce the total cost of asphalt mix. This waste plastic modified asphalt is a great water proof which make road more resistible again water action which Coues pothole in road.

\section{Data of Waste Plastic Generation in Pakistan}

Table 1. Population Estimation of Pakistan

\begin{tabular}{|c|c|c|c|c|c|}
\hline \multirow{2}{*}{$\begin{array}{l}\text { S. } \\
\text { No }\end{array}$} & \multirow{2}{*}{ Major Cities } & \multirow{2}{*}{$\begin{array}{c}\text { Census } \\
1981\end{array}$} & \multicolumn{3}{|c|}{ Estimates (000's) } \\
\hline & & & 1996 & 2006 & 2016 \\
\hline 1 & Quetta & 286 & 1,000 & 2,004 & 4,017 \\
\hline 2 & Gujranwala & 601 & 1,759 & 3,596 & 7,361 \\
\hline 3 & Faisalabad & 1,104 & 2,364 & 3,928 & 6,528 \\
\hline 4 & Karachi & 5,208 & 10,522 & 16,816 & 26,873 \\
\hline 5 & Hyderabad & 911 & 1,733 & 2,661 & 4,085 \\
\hline 6 & Peshawar & 717 & 1,655 & 2,403 & 3,489 \\
\hline & Total & 8,827 & 19,033 & 31,408 & 52,353 \\
\hline
\end{tabular}

Source: PEPA GUIDELNE FOR SWM 2005

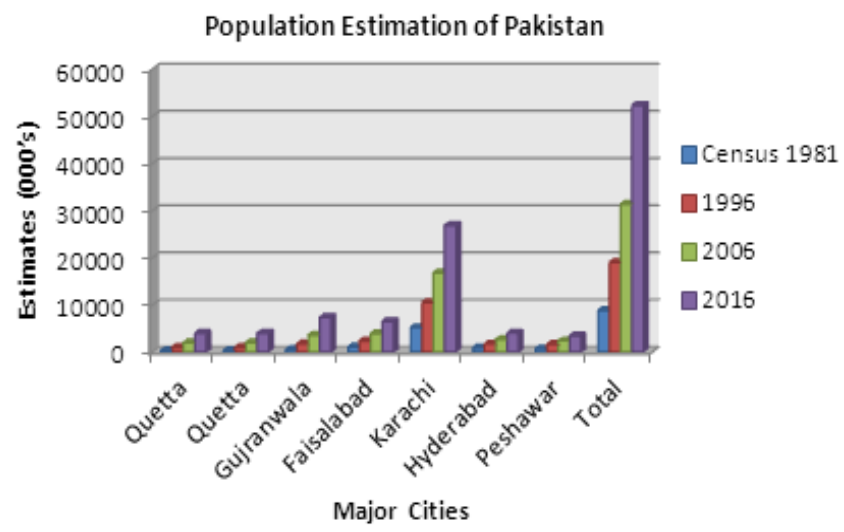

The collection, disposal and transportation of solid waste have not been carried out in an adequate and suitable manner in Pakistan which result a worse sanitary and environmental conditions. During 1996 the ministry of environmental and urban division government of Pakistan undertook a study on privatization of some major selected cities solid waste management in Pakistan. From this study the Population Estimation of Pakistan, Solid Waste Generation in Pakistan 
and Plastic Waste Generation in Pakistan were calculated to have a rough estimate of total amount of plastic generated in some major cities of Pakistan.

Table 2. Solid Waste Generation in Pakistan

\begin{tabular}{|c|c|c|c|c|}
\hline \multirow{2}{*}{$\begin{array}{c}\text { S. } \\
\text { No }\end{array}$} & \multirow{2}{*}{$\begin{array}{c}\text { Major } \\
\text { Cities }\end{array}$} & \multirow{2}{*}{$\begin{array}{c}\text { Generation } \\
\text { Kg/C/day }\end{array}$} & \multicolumn{2}{|c|}{ Waste Generated } \\
\cline { 4 - 5 } $\mathbf{1}$ & Quetta & 0.378 & 757.51 & 276491.15 \\
\hline $\mathbf{2}$ & Gujranwala & 0.469 & 1686.52 & 615579.8 \\
\hline $\mathbf{3}$ & Faisalabad & 0.391 & 1535.85 & 560585.25 \\
\hline $\mathbf{4}$ & Karachi & 0.613 & 10308.21 & 3762496.65 \\
\hline $\mathbf{5}$ & Hyderabad & 0.563 & 1498.14 & 546821.1 \\
\hline $\mathbf{6}$ & Peshawar & 0.489 & 1175.07 & 428900.55 \\
\hline & Total & & 16961.3 & 6190874.5 \\
\hline
\end{tabular}

Source: PEPA GUIDELNE FOR SWM 2005

Table 3. Plastic Waste Generation in Pakistan

\begin{tabular}{|c|c|c|c|c|c|}
\hline \multirow{2}{*}{$\begin{array}{c}\text { S. } \\
\text { No }\end{array}$} & \multirow{2}{*}{$\begin{array}{c}\text { Major } \\
\text { Cities }\end{array}$} & \multirow{2}{*}{$\begin{array}{c}\text { Plastic } \\
\mathbf{\%}\end{array}$} & \multirow{2}{*}{$\begin{array}{c}\text { Generation } \\
\text { Kg/C/day }\end{array}$} & \multicolumn{2}{|c|}{$\begin{array}{c}\text { Plastic Waste } \\
\text { Generated }\end{array}$} \\
\cline { 5 - 6 } $\mathbf{1}$ & Quetta & 8.2 & 0.030996 & 62.11582 & 22672.27 \\
\hline $\mathbf{2}$ & Gujranwala & 5.00 & 0.02345 & 84.326 & 30778.99 \\
\hline $\mathbf{3}$ & Faisalabad & 4.80 & 0.018768 & 73.7208 & 26908.09 \\
\hline $\mathbf{4}$ & Karachi & 6.40 & 0.039232 & 659.72544 & 240799.8 \\
\hline $\mathbf{5}$ & Hyderabad & 3.60 & 0.020268 & 53.93304 & 19685.56 \\
\hline $\mathbf{6}$ & Peshawar & 3.70 & 0.018093 & 43.47759 & 15869.32 \\
\hline & Total & & & 977.29869 & 356714 \\
\hline
\end{tabular}

Source: PEPA GUIDELNE FOR SWM 2005

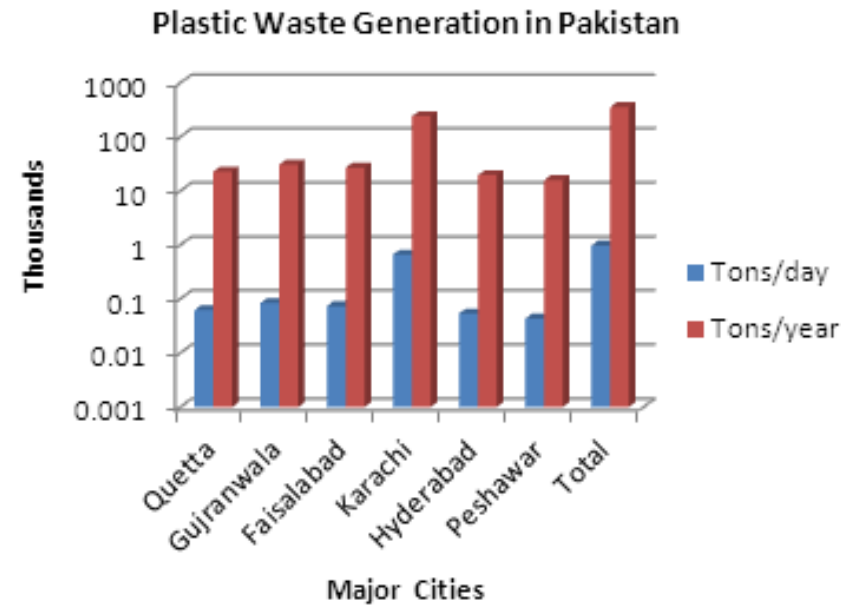

Characterization of Waste Plastics

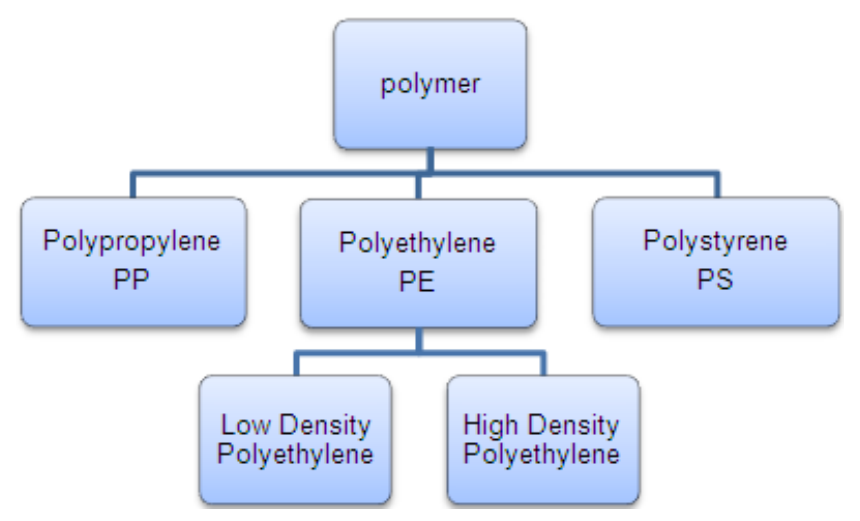

Thermal Study

Polymers thermal behavior is shows in Table 4 .

Table 4. Thermal Behavior of Polymers

\begin{tabular}{|c|c|c|c|c|c|}
\hline Polymer & $\begin{array}{c}\text { Solubility } \\
\text { in water \% }\end{array}$ & $\begin{array}{c}\text { Softening } \\
\text { Temp. F }\end{array}$ & $\begin{array}{c}\text { Products } \\
\text { Reported }\end{array}$ & $\begin{array}{c}\text { Decomposition } \\
\text { Temp. F }\end{array}$ & $\begin{array}{c}\text { Products } \\
\text { Reported }\end{array}$ \\
\hline Polystyrene & 0 & $230-284$ & No Gas & $572-662$ & C6H6 \\
\hline Polyethylene & 0 & $212-248$ & No Gas & $518-662$ & CH4,C2H6 \\
\hline Polypropylene & 0 & $284-320$ & No Gas & $518-572$ & C2H6 \\
\hline
\end{tabular}

Table 5. Specification of Bitumen

\begin{tabular}{|c|c|c|c|c|c|}
\hline $\begin{array}{c}\text { S. } \\
\text { No. }\end{array}$ & Test Description & $\begin{array}{c}\text { Test } \\
\text { Method }\end{array}$ & $\begin{array}{c}\text { AASHTO* } \\
\text { M-20 }\end{array}$ & Max/Min & Units \\
\hline $\mathbf{1}$ & Flash Point, COC & D92 & 232 & Min & ${ }^{\circ} \mathrm{C}$ \\
\hline $\mathbf{2}$ & Penetration @ $25^{\circ} \mathrm{C}$ & D5 & $60-70$ & - & $\begin{array}{c}1 / 10 \\
\mathrm{~mm}\end{array}$ \\
\hline $\mathbf{3}$ & Ductility @ $25^{\circ} \mathrm{C}$ & D113 & 100 & Min & $\mathrm{cm}$ \\
\hline $\mathbf{4}$ & Solubility in Trichloroethylene & IP47 & 99 & Min & $\mathrm{Wt} \%$ \\
\hline
\end{tabular}

* American Association of State Highway and Transportation Officials 


\section{Bitumen}

Bitumen is highly viscous and sticky black semi-solid or liquid form of petroleum. It can be a refined product or may be found in natural deposits. The main use of bitumen is as binder in road construction. For pavement purpose Various Grades of Bitumen are used such as Grade: 60/70; Grade: $80 / 100$ etc. but the one used in this research paper is Grade 60/70 from Attock Refinery Limited Rawalpindi, Pakistan. The Specification of bitumen used in tests are given in table 5 .

\section{Methodology}

Plastic bags were collected from dumpsites, garbage trucks, roads, rag pickers and waste-buyers at Rs 10-15 per $\mathrm{kg}$. Used plastic bags were also collected from houses for project work. The plastic bags that were collected was classified to required thickness and plastic bags with up to 60 micron was selected because the mixing of these begs with bitumen were easy at laboratory level with a mixing temperature about $160^{\circ} \mathrm{c}-170^{\circ} \mathrm{c}$ as it's the softening point of LDPE. The bags were first cleaned and then were cut to small pieces so that it could pass sieve no. 4 . The plastic bags pieces retained on sieve no. 4 were rejected. Bitumen was heated to $160^{\circ} \mathrm{c}-170^{\circ} \mathrm{c}$ and plastic pieces were slowly added with constant staring for about 30 minutes. Then pre heated aggregate was added and hot asphalt mix was prepared and Marshal Moulds were prepared with 75 blows compaction on each side and these sample were then tested to find the difference between normal bitumen and polymer modified bitumen in term of Marshall Stability and Flow vales the plastic vale was increased with keeping bitumen value constant to see the effect of plastic on strength and flow.

\section{Result}

The results show that initially the strength was increased by the addition of plastic where the flow was decreased but as the plastic percentage was increased the strength got increasing but on the other hand flow also star getting increased. but at $10 \%$ the flow was almost the same as it was for the $0 \%$ plastic so up to $10 \%$ plastic can be added to modify bitumen for more strength with same flow as that for ) $\%$ plastic.

Table 6. Test Result

\begin{tabular}{|c|c|c|c|c|}
\hline S. No. & LDPE \% & Bitumen \% & $\begin{array}{c}\text { Marshal } \\
\text { Stability } \\
(\mathbf{K N})\end{array}$ & $\begin{array}{c}\text { Flow Value } \\
(\mathbf{m m})\end{array}$ \\
\hline $\mathbf{1}$ & 0 & 3 & 12.32 & 3.70 \\
\hline $\mathbf{2}$ & 3 & 3 & 13.13 & 3.00 \\
\hline $\mathbf{3}$ & 6 & 3 & 13.98 & 3.01 \\
\hline $\mathbf{4}$ & 9 & 3 & 15.125 & 3.3 \\
\hline $\mathbf{5}$ & 10 & 3 & 18.97 & 3.775 \\
\hline $\mathbf{6}$ & 11 & 3 & 19.87 & 3.8 \\
\hline $\mathbf{7}$ & 12 & 3 & 20.285 & 3.825 \\
\hline $\mathbf{8}$ & 15 & 3 & 22.18 & 4.05 \\
\hline
\end{tabular}

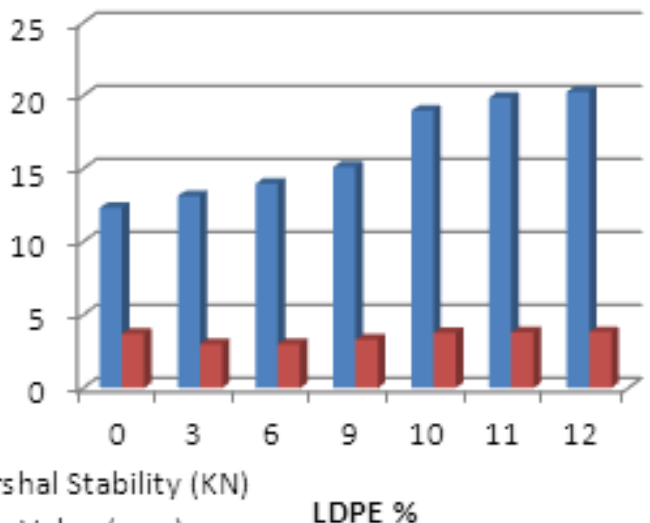

- Flow Value $(\mathrm{mm})$

\section{Conclusions}

To discover useful ways to reutilize the waste plastic was the key purpose of this paper. Polypropylene, polystyrene and polyethylene are major polymers that show adhesion property in their molten state. The strength parameter of Hot Asphalt Mix that is Marshal Stability value shows increasing trend and the highest values have improved by about $65 \%$ by addition of $10 \%$ of LDPE by the weight of bitumen where the flow is the same as it was for $0 \%$ plastic. This will provide more stable and durable mix for the flexible pavements. The serviceability and resistance to moisture will also be better when compared to the conventional method of construction. This study not only constructively utilizes the waste plastic but it has also effectively enhanced the important parameters which will ultimately have better and long living roads. Hence the best way for easy disposal of waste plastics is to utilize it as bitumen modifier for flexible pavements. This will not only improves the life and performance of pavement but will also provide a use full disposable of waste plastic with reducing usage of bitumen. The procedure is environment affable. Let us adopt this newer technology to only to clean our environment form waste plastic but also to have long life roads with greet strength and weather resistance.

\section{REFERENCES}

[1] Solid waste management Draft Available from: http://www.environment.gov.pk/info.htm.

[2] plastic bag Available from: http://en.wikipedia.org/wiki/Plastic_bag.

[3] Justo C.E.G., V.A., Utilization of Waste Plastic Bags in Bituminous Mix for Improved Performance of Roads.

[4] R, V., Utilization of waste plastics for flexible pavement. Indian Highways (Indian Road Congress), 2006.. vol. 34: p. pp 105-111.

[5] R. Vasudevan, S.K.N., R. Velkennedy, A. Ramalinga 
Chandra Sekar and B. Sundarakannan,, Utilization of Waste Polymers for Flexible Pavement and Easy Disposal of Waste Polymers, Proceedings of the International Conference on Sustainable Solid Waste Management. 2007: p. pp. 105-111.

[6] s.s, V., Roads from Waste Plastic. The Indian concrete journal, 2008: p. pp 43-47.

[7] Sabina, K.T.A., Sangita, Sharma D.K., Sharma B.M, Performance Evalution. of Waste Plastic/ Polymers Modified
Bituminious Concrete Mixes. Journal of Scientific and Industrial Research 2009. vol.68.

[8] T. Awwad Mohammad, S.L., The Use of Polyethylene in Hot Asphalt Mixtures. American Journal of Applied Sciences 2007. 4: p. pp 390-396,.

[9] Yue Huang, R.N.B., Oliver Heidrich, A review of the use of recycled solid waste materials in asphalt pavements Resources. Conservation and Recycling 2007: p. pp 58-73. 